\title{
DEVELOPMENT OF AN INTEGRATION MODEL OF DAMAGE ASSESSMENT FOR MANGROVE ECOSYSTEM DUE TO OIL SPILL IN PELENG STRAIT, BANGGAI, AND BANGGAI ISLANDS REGENCY, CENTRAL SULAWESI
}

\author{
Putranto, S.* - ZAMAni, N. P. - SAnUsi, H. S. - Riani, E. - FAhrudin, A. \\ Department of Marine Science, Faculty of Fisheries and Marine Science, Agriculture University \\ of Bogor, Bogor, West Java, Indonesia \\ (e-mail: itkipb@ipb.ac.id; phone: +62-251-862-3644; fax: +62-251-862-3644) \\ *Corresponding author \\ e-mail: sugeng.putranto@yahoo.com; phone: +62-811-177-2375
}

(Received 20 $0^{\text {th }}$ Aug 2018; accepted $1^{\text {st }}$ Nov 2018)

\begin{abstract}
Oil spills in the marine environment can cause damage to mangrove ecosystems. Assessment of mangrove ecosystem damage can be done by analyzing mangrove sensitivity index, oil spill model and economic value calculation. The aim of research is to develop an integrated model of damage assessment of mangrove ecosystems. Furthermore, some data are needed, there are: important value index of mangrove, economic valuation of mangrove ecosystems, oil distribution patterns and the loos value of mangrove that contaminated by the oil spill, which is integration on development model to damage mangrove ecosystems. The research was conducted in nine districts in Central Sulawesi from August to November 2016, obtaining samples and interviews with the community and local government. Areas with moderate sensitivity are located in Balantak, Buko, Masama, Lamala, Luwuk Timur, Bualemo dan Batui districts, with the value is about 10,67-22,69. The value of MSI with sensitive category ranging of 35,214492 in Bulagi and South Batui district. The analysis result is Total Economic Value (TEV) at the research location is Rp 22.644.656.169 / year, with the highest economic valuation obtained from indirect mangrove benefit that is as coastal protection, the value reached Rp 16,455,794,485/year (72.67\%). The comparation of loss value using approach method of organism response is better compared with approach of generic method, because not assuming $100 \%$ mangrove is dead however only sensitive mangrove will die $(<3 \mathrm{~m})$ and the integration model can display spatially the distribution of oil spills, the value of mangrove sensitivity index and the value of environmental damage to mangrove ecosystems.
\end{abstract}

Keywords: economic value, mangrove ecosystem, oil spill, Peleng strait, Banggai district, Banggai islands, Central Sulawesi province

\section{Introduction}

Indonesia has experienced several oil spill incidents, one of which occurred in the Montara well head platform in the Timor Sea in 2009. Although the oil spill location was in Australia's Zee territory, the impact was felt in Indonesia in eight districts in East Nusa Tenggara province (Mainarni, 2016). The government of Indonesia claimed environmental damage caused by the oil spill of about US\$2.4 billion or Rp 21.6 trillion. Unfortunately, the claim was rejected by Pt Tep Australasia because it was not supported by enough data (Republika, 2010). The recent incident was in April 2018, the oil spill in Balikpapan Bay. Approximately 7,000 ha, with the length of the affected coast on the side of Balikpapan and Penajam Paser Utara reaches $60 \mathrm{~km}$. Satellite analysis results on April 2, 2018 estimate the total area of oil spill in Balikpapan Bay reached 12,987.2 ha. This oil spill reached the mangrove area around Balikpapan Bay, which is about 6,000 ha in Kampung Atas Air Margasari. And 2,000 mangrove seeds in Kampung Atas Air Margasari (Tempo, 2018). 
Assessment of ecosystem damage can be done by analyzing mangrove sensitivity index, oil spill model and economic value calculation. The development of mathematical models and the application of the Geographic Information System (GIS) have been carried out in the Malacca Strait, Lombok Strait and Makassar Strait to see the distribution patterns of oil spills, the number and extent of areas affected by oil spills (Hadi and Latief, 2010). Environmental Sensitivity Index (ESI) is used to map environmental sensitivity to oil spills in the waters of Pramuka Island, Panggang, Semak Daun and Karang Congkak. This Environmental Sensitivity Index will identify the characteristics of environmental sensitivity through mapping natural resources and land use in coastal areas (Fatullah, 2009).

Until now limited model integration has only combined the environmental sensitivity index with the oil spill model and has not combined the economic value of mangrove ecosystem damage, for example from several studies or studies, including the Mapping of Environmental Sensitive Index (ESI) for the oil spills at Goa Coast, India by Murali and Kumar (2009), Mapping the Impacts of Crude Oil theft and Illegal Refineries on Mangrove of the Niger Delta of Nigeria with Remote Sensing Technology by Balogun (2015) and Environmental Sensitivity Index Mapping of Lagos Shorelines by Oyedepo JA and Adeofun CO (2011). Likewise with the results of research or studies in Indonesia that still use the integrase between IKL and Oil Spill, such as PHE ONWJ (2009), BP Tangguh (2012), and Donggi Sinoro LNG (2012).

Based on this background, the purpose of this research is develop an integrated model of damage assessment to mangrove ecosystem due to oil spills that using i, oil spill model and economic valuation. The following framework of thought from this research as shown in Figure 1.

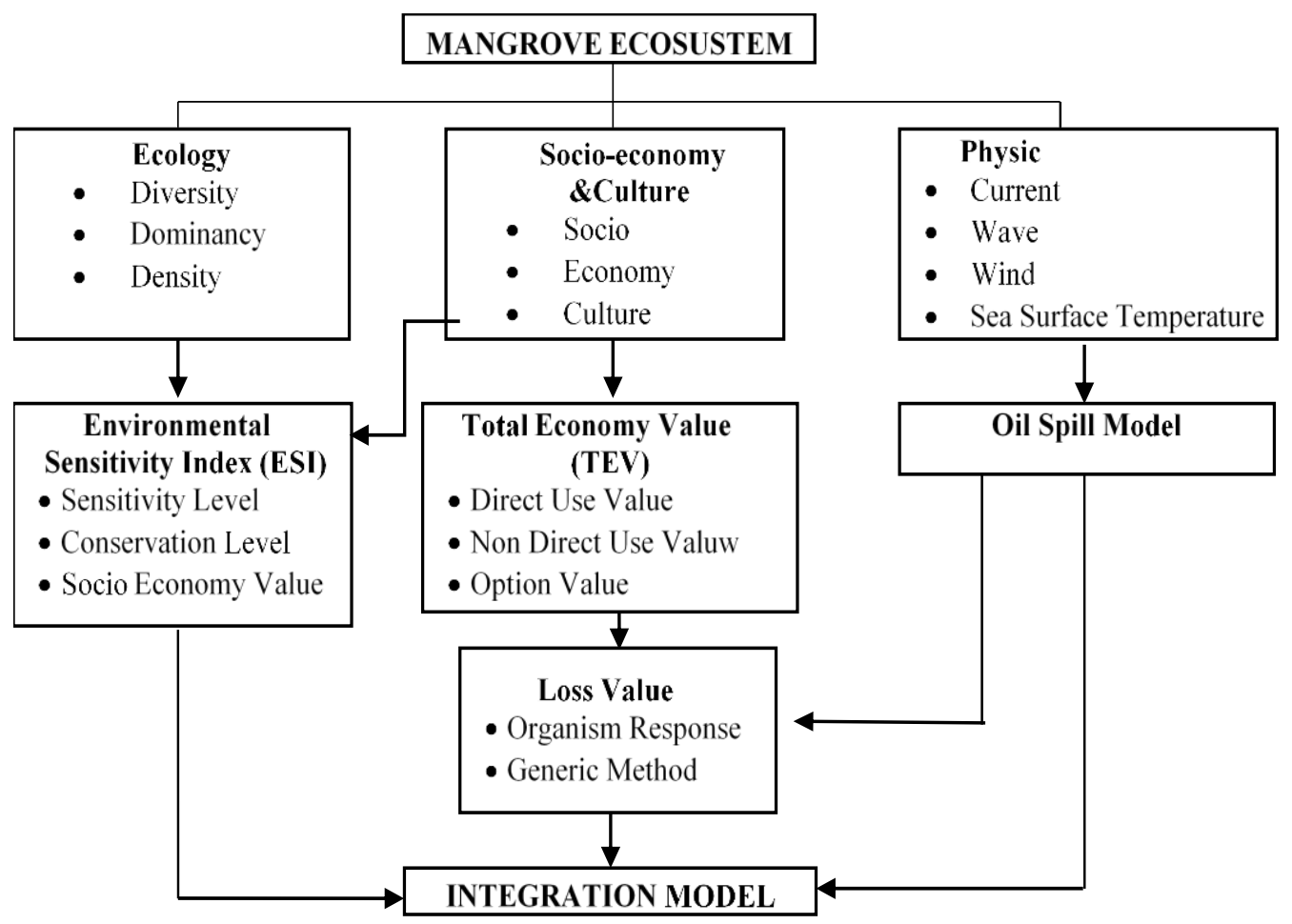

Figure 1. Flowchart of integration model 


\section{Research method}

\section{Location and time}

Data observation was conducted in the mangrove ecosystem area in Banggai Regency and Banggai Islands Regency, Central Sulawesi. The research was performed in August-November 2016. Data were collected from nine districts: South Batui, Batui, East Luwuk, Lamala, Masama, Balantak and Bualemo (Banggai Regency), and Bulagi and Buko (Banggai Island Regency) (Fig. 2).

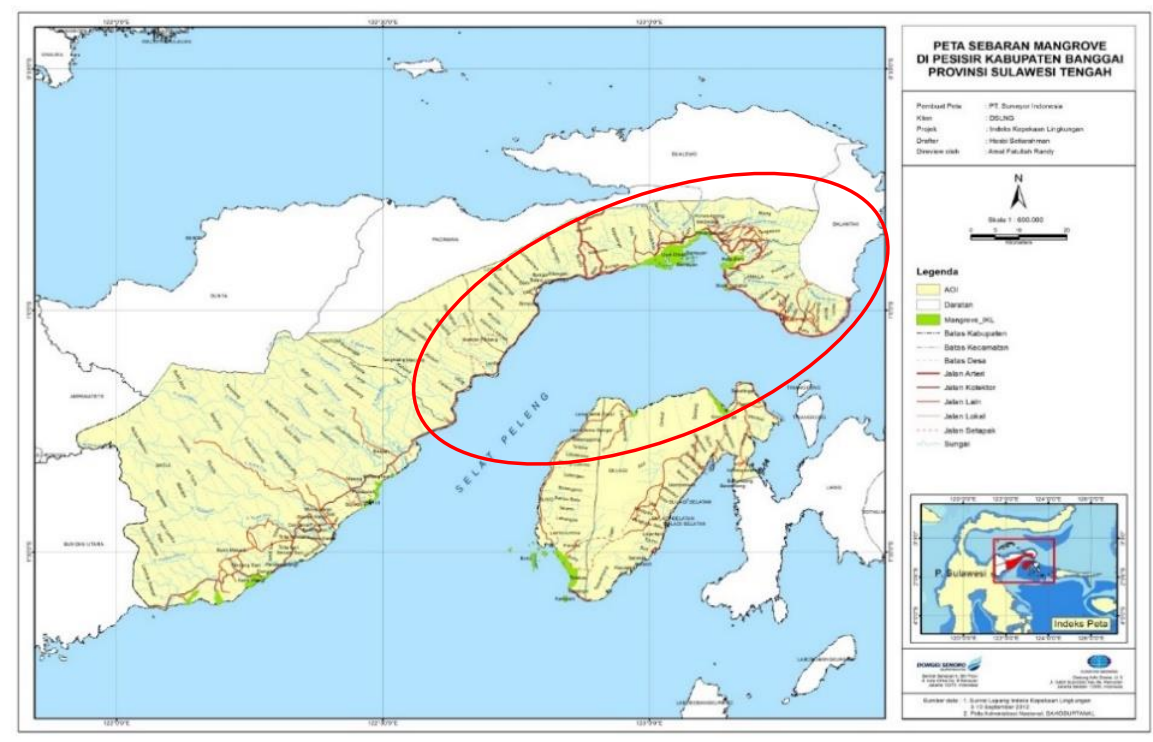

Figure 2. Boundary of research location

\section{Data collection technique}

\section{Mangrove}

Mangrove density was measured by the line transect plot method with a $10 \times 10-\mathrm{m}$ transect on each vertical/horizontal stratification zone (three plots for data retrieval and repetition). The distance between each plot is about $20 \mathrm{~m}$, with coordinate points recorded by GPS locations. The diameter measurement for individual mangroves refers to the Ministry of Environment no. 201 the year 2004 regarding the Standard and Guideline of Mangrove Degradation. The species identification refers to (Giesen et al., 2006). Height, radius, diameter of mangrove plant used roll meter with the scale of accuracy of $1 \mathrm{~cm}$.

\section{Economic valuation}

The sampling method was accidental sampling taken from the people who live in the mangrove area. Based on pre-research, about 81 respondents work as fishermen, woodmen, or in jobs related to mangrove resources. Primary data were obtained by deep interview and questionnaires (directly collecting the data from the local community), and secondary data were collected from the local government officials and other resources. 


\section{Oil spill}

According to Hoff et al. (2014), the oil can be divided into five groups as shown in Table 1 based on common behavior and nature. Concept of drafting the spatio-temporal model is shown in Figure 3. The oil spill model uses Oilmap software. This model can predict the spread of oil spills. The software uses a geographic information system that combines the environmental conditions and the oil characteristics. Secondary data were used for the distribution of the oil spill regarding the daily/monthly tide and annual tide, currents, waves, wind, and humidity. These data were obtained from the Luwuk Climatology and the North Oceanic Atmospheric Administration (NOAA) databases.

Table 1. Data collection technique

\begin{tabular}{|c|c|c|}
\hline No. & Parameter & Method of collecting data \\
\hline 1 & $\begin{array}{l}\text { Mangrove } \\
\text { community }\end{array}$ & $\begin{array}{l}\text { The measurement method of mangrove communities uses stratification sampling } \\
\text { with a square plot of } 10 \times 10 \mathrm{~m} \\
\text { Retrieved data are in two locations starting from the coast to the mainland (plot 1) } \\
\text { and parallel with the coastal (plot } 2 \text { ). The length of each plot is } 50-100 \mathrm{~m} \text {, } \\
\text { depending on the mangrove density } \\
\text { Observation of the species, the number of trees, and seedlings from the mangrove } \\
\text { vegetation in the plot one by one } \\
\text { Measure the diameter and height of each mangrove tree }\end{array}$ \\
\hline 2 & Oil spill & $\begin{array}{l}\text { Develop a model of the distribution of the oil spill using the software Oilmap } \\
\text { Literature study }\end{array}$ \\
\hline 3 & $\begin{array}{l}\text { Economic } \\
\text { valuation }\end{array}$ & $\begin{array}{l}\text { Socioeconomic survey with deep interview questionnaire } \\
\text { Field survey: } \\
\text { Primary data consisted of mangrove forest condition regarding the type, density, } \\
\text { frequency, closing, and par value } \\
\text { The data consisted of questionnaire data of economic valuation variables of } \\
\text { mangrove forest, community profile, respondents' view of the mangrove forest, } \\
\text { and community interaction } \\
\text { Secondary data obtained from the local government included a dynamic and static } \\
\text { village monograph } \\
\text { Literature study }\end{array}$ \\
\hline 4 & $\begin{array}{l}\text { Determination of } \\
\text { loss values }\end{array}$ & $\begin{array}{l}\text { Par value of mangrove trees is calculated by the oil spill impacting the mangrove } \\
\text { plants of less than } 3-\mathrm{m} \text { height } \\
\text { Par value of mangrove crab is calculated by considering the death impact on days } \\
0-15 \text { so that the annual percentage of death is } 100 \% \text { per year } \\
\text { Biological par value is calculated by the number of biota deaths around the } \\
\text { mangrove forest with the deadly impact on days } 0-15 \text { so that the annual } \\
\text { percentage of death is } 100 \% \text { per year } \\
\text { Physical par value is calculated by the existence of mangrove forests, which is } \\
\text { equal to the par value of mangrove tree calculation } \\
\text { Par value of option calculation is similar to the par value of mangrove trees and } \\
\text { physical par value }\end{array}$ \\
\hline 5 & Integration model & $\begin{array}{l}\text { - Calculate and visualize spatially the value of Mangrove Sensitivity Index (MSI) } \\
\text { - Integrating oil spill models with spatial analysis of MSI } \\
\text { - Calculation of the damage value of mangrove ecosystems is also integrated with } \\
\text { the spatial analysis of MSI } \\
\text { - The results of the integration model of damage to mangrove ecosystem damage } \\
\text { were visualized sepasially by displaying the distribution of oil spills, the value of } \\
\text { the sensitivity index of mangroves and the value of environmental damage to } \\
\text { mangrove ecosystems }\end{array}$ \\
\hline
\end{tabular}




\section{Data analysis}

\section{Mangrove sensitivity index}

Data on mangrove vegetation will be analyzed as quantitatively descriptive. The recorded data from site observation were analyzed to calculate Mangrove Sensitivity Index. (Mangrove community structure equation which includes: number of species (J) diversity index $\left(\mathrm{H}^{\prime}\right)$, type dominance index (DJ), and density of mangroves $(\mathrm{P})$ while in calculating the MSI (Mangrove Sensitivity Index) of Mangrove refers on the threecomponent determinant approach, namely Vulnerability Level (VL), Conservation Value (CV) and Social and Economic Value (SEV), then MSI is a function of the three components (Sloan, 1993), namely:

$$
M S I=V L \times C V X S E V
$$

Presented in Table 2 is the score or grouping value of the mangrove sensitivity index (MSI).

Table 2. Grouping of sensitivity levels. (Sumber: NOAA, 2001)

\begin{tabular}{c|c}
\hline ESI scores & Sensitivity level \\
\hline 1 & No sensitive \\
$2-8$ & Slightly sensitive \\
$9-27$ & Moderate \\
$28-64$ & Sensitive \\
$65-125$ & Very sensitive \\
\hline
\end{tabular}

\section{Vulnerability level}

The value of vulnerability level mangrove is a modification of Sloan (1993) constructed of 2 variables that include the value of diversity $\left(\mathrm{H}^{\prime}\right)$ and the dominance of (DJ). The calculation vulnerability level of mangrove (VL) is the root of the second rank 2 of multiplication of variables.

$$
V L_{\text {mangrove }}=\sqrt{H^{\prime} x D J}
$$

\section{Conservation value}

The conservation value of mangrove, built from layer 4 variables include the degree of density of trees $(\mathrm{P})$, the number of types $(\mathrm{J})$, the distance from the river bank (D), and the distance of the farthest inland reaches of sea water $(\mathrm{R})$. The calculation of the value of conservation of mangrove $(\mathrm{CV})$ is the root of rank 4 from four multiply the variables, or it is a geometric average (geometric mean) of the four variables, which are formulated (Sloan, 1993) as follows:

$$
C V_{\text {mangrove }}=\sqrt[4]{P x J x D x R}
$$

$\underline{\text { Social economy value }}$

Social economic value of mangrove in layer constructed from 3 variables i.e. Services ecosystem (SE), local rules (LR), and cultural values (CB). Calculation of 
social economy value (SEV) is the root of mangrove rank 3 of multiplication of these variables, or third is geometric average (geometric mean) of these three variables (Sloan, 1993), which is formulated as follows:

$$
S E V_{\text {manarove }}=\sqrt[\pi]{S E x L R \times C B}
$$

\section{Economic valuation of mangrove ecosystem}

Economic valuation of mangrove ecosystem resources or total economic value (TEV) is calculated from the sum of economic value based on utilization, which includes direct value, indirect value, and option value (Sambu and Rahmi, 2014). The following is the analysis method for economic valuation of mangrove ecosystems:

$$
T E V=D U V+I U V+O V
$$

where:

Total Economic Value (TEV): Measured in terminology as a willingness to pay (WTP). Direct Use Value (DUV): Goods and services provided by a resource that can be directly utilized.

Indirect Use Value (IUV): The value is derived from the goods and services provided by natural resources that can be used indirectly

Option Value (OV): Potential direct or indirect value of a natural resource that can be utilized in the future, assuming that the resource is not destroyed or permanently damaged

Direct use value

Benefit wood log value

Calculated based on the data of forest, wood density and diameter, then the data were analyzed based on instructions Wantasen (2002) as follows:

\section{Benefit Wood Log Value $=(V \times$ total $) \times$ price $/ m 3$}

$$
V=\pi r^{2} t
$$

where:

$$
\begin{aligned}
& \mathrm{V}=\text { Volume }\left(\mathrm{m}^{3}\right) \\
& \pi=3.14 \\
& \mathrm{r}=\text { Radius } \\
& \mathrm{t}=\text { Height }(\mathrm{m})
\end{aligned}
$$

Benefit crab value

The value of the benefit is calculated based on the amount of crab catches per year multiplied by the selling price.

$$
\text { Benefit Crab Value }=(T x H)-B(R p / h a / y r)
$$

where:

$$
\begin{aligned}
& \mathrm{T}=\text { Caught crab }(\mathrm{kg} / \mathrm{ha} / \mathrm{yr}) \\
& \mathrm{H}=\text { Selling price }(\mathrm{Rp} / \mathrm{kg})
\end{aligned}
$$




$$
\text { - } 8005 \text { - }
$$

$\mathrm{B}=$ Operational Wesel $(\mathrm{Rp})$

\section{Indirect use value}

Biology uses

Indirect benefits of mangrove ecosystems where spawning fish (spawning ground). Initial benefits (price) multiplied by the number of catches in about mangroves reduced investment and operational money (assuming the functions of the initials are spread evenly). The calculation of value in benefit does not include initials of the fish offshore that are considered not utilizing zero forest functions.

$$
\text { Benefit Biology Value }=(\text { T } x H)-B(R p / h a / y r)
$$

$\mathrm{T}=$ Caught fish $(\mathrm{kg} / \mathrm{ha} / \mathrm{yr})$

$\mathrm{H}=$ Selling price $(\mathrm{Rp} / \mathrm{kg})$

$\mathrm{B}=$ Operational Wesel $(\mathrm{Rp})$

\section{Physical uses}

Mangrove ecosystems also serve as protectors of the coast from ocean waves. The value of the initial benefits are calculated through the concrete making money order approach is equivalent to the function of mangrove forests as anchoring abrasion. According to Candy PUPR No. 28 year 2016, to create a breakwater with a building the size of a $150 \mathrm{~m}$ long, $20 \mathrm{~m}$ wide and $5 \mathrm{~m}$ high with a 10 -year durability needed cost amounting to $\mathrm{Rp} 2,921,147,000$ or $\mathrm{Rp} 19,474,313$ per meter. That number is multiplied by the length of the coastline, then it can be calculated with the following formula:

$$
\text { Benefit Physic Value }=\frac{B \times P G P}{10(R p / h a / y r)}
$$

$\mathrm{B}=$ Concrete standard wesel $(\mathrm{Rp})$

Pgp $=$ Coast line $(\mathrm{m})$

$\mathrm{Dt}=$ Durability $(\mathrm{yr})$

Option value

Benefits option value can be known by using the direct method. Value the benefits choices research results (Ruintenbeek, 1992). § Taxes US\$ $1,500 / \mathrm{km}^{2} / \mathrm{yr}$ may also serve as a reference point, assuming the ecological functioning of the mangroves is important and will remain preserved.

Par value the benefits of biodiversity $=U S \$$ halyear $\times$ Extensive Mangrove Forests $\times$ Kurs Rupiah exchange to dollar

The spread of an oil spill

The oil spill area in a mangrove ecosystem is determined using a stochastic model. A stochastic model estimates the magnitude of Marine Fuel Oil (MFO) that entered the mangrove ecosystem and then predicts the travel time for the oil to reach the shoreline and the percentage of stranded oil on the shore. 


\section{Determination of loss values}

To calculate the loss values, refer to the research results from Getter (1984) in Hoff and Michel (2014), as shown in Table 3. The analysis method to calculate mangrove damage is as follows:

1. Par value of mangrove trees is calculated by the oil spill impacting the mangrove plants of less than $3 \mathrm{~m}$ in height.

2. Par value of mangrove crab is calculated by considering the death impact on days $0-15$ so that the annual percentage of death is $100 \%$ per year.

3. Biological par value is calculated by the number of biota death around the mangrove forest with the deadly impact on days $0-15$ so that the annual percentage of death is $100 \%$ per year.

4. Physical par value is calculated by the existence of mangrove forests, which is equal to the par value of mangrove tree calculation.

5. Par value of option calculation is similar to the par value of mangrove trees and physical par value.

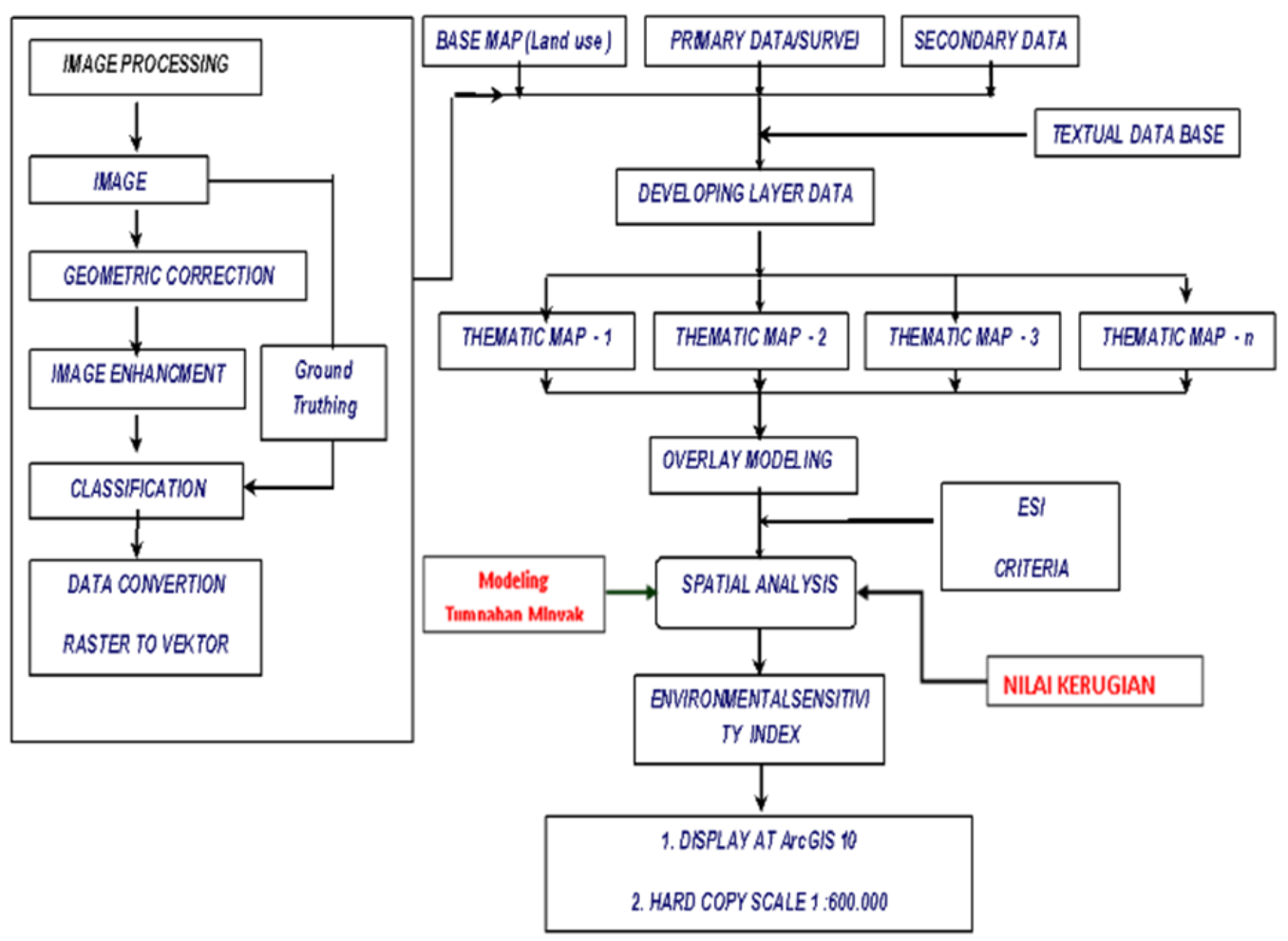

Figure 3. The concept of drafting the spatio-temporal model

Table 3. The value of the loss is based on the percentage of damage in each par value

\begin{tabular}{c|c}
\hline Parameter & Percentage of damage \\
\hline Par value of wood & Percentage of mangroves height $<3 \mathrm{~m}$ \\
Par value of crab & $100 \%$ \\
Biological value of crab & $100 \%$ \\
Physical value of crab & Calculated from the percentage of tree damage \\
Par value of the option & Calculated from the percentage of tree damage \\
\hline
\end{tabular}




\section{Integration model}

This simulation will integrate the oil spill trajectory, environmental sensitivity index (ESI), and economic values, which will be displayed in the form of a thematic map containing the value of the damage. This thematic map uses the GIS and Oil map arcs combined with the formulation of economic valuations. Oil trajectory data were simulated by incorporating oceanographic and climatological parameters. This spatial simulation will contain information on the cost of mangrove ecosystem damage due to oil spills in two different scenarios and four seasons.

\section{Result and discussion}

\section{Composition of mangrove species and ESI}

There are 14 mangrove species found in Banggai Regency, consisting of six major species (Rhizophora mucronata, Bruguiera gymnorhiza, Bruguiera parviflora, Ceriopstagal, Avicennia marina, and Sonneratia alba), four minor species (Aegicerascorniculatum, Aegicerasfloridum, Xylocarpusgranatum, and Excoecariaagallocha), and four types of mangrove associations (Myristica hollrungii, Pandanus tectorius, Calophyllum inopillum, and Nypa sp.). Rhizophora mucronata is found in every location, except East Luwuk, due to its high tolerance of environmental conditions, especially regarding substrate, tides, salinity, and nutrient supply, and because the propagule can distribute anywhere in a large area and grow in various places. This species has striking features, such as propping and woody roots, a tip covered by red tape leaves, and sprouted fruit while still hanging on the tree (Tomlinson, 1986). Balantak is the region with the highest variety, featuring seven species of mangrove. This indicates that the area is more heterogeneous than other areas, meaning that the environmental conditions of both salinity and substrate can be tolerated by various types of mangroves, which receive their nutrient supply and sedimentation from the river. The following map of the distribution of the mangrove sensitivity index is shown in Figure 4.

The results of spatial analysis of ESI in the coastal areas of Banggai and Banggai Islands are obtained from sensitivity values of medium and sensitive. Areas with moderate sensitivity are North Balantak, South Buko, Masama, Lamala, East Luwuk and Batui sub-districts with grades between 10.67- 22.69. The value of ESI with sensitive category ranges from 35.21 to 44.92 in South Batui and North Bulagi subdistricts (Table 4).

Table 4. The level of sensitivity in districts on the area of study

\begin{tabular}{c|c|c|c}
\hline District & MSI (moderate) & District & MSI (Sensitive) \\
\hline Balantak & 22.69 & Bulagi & 44.92 \\
Buko & 21,5 & Batui Selatan & 35.21 \\
Masama & 16.45 & & \\
Lamala & 15.19 & & \\
Luwuk Timur & 15.11 & & \\
Bualemo & 13.77 & & \\
Batui & 10.67 & & \\
\hline
\end{tabular}




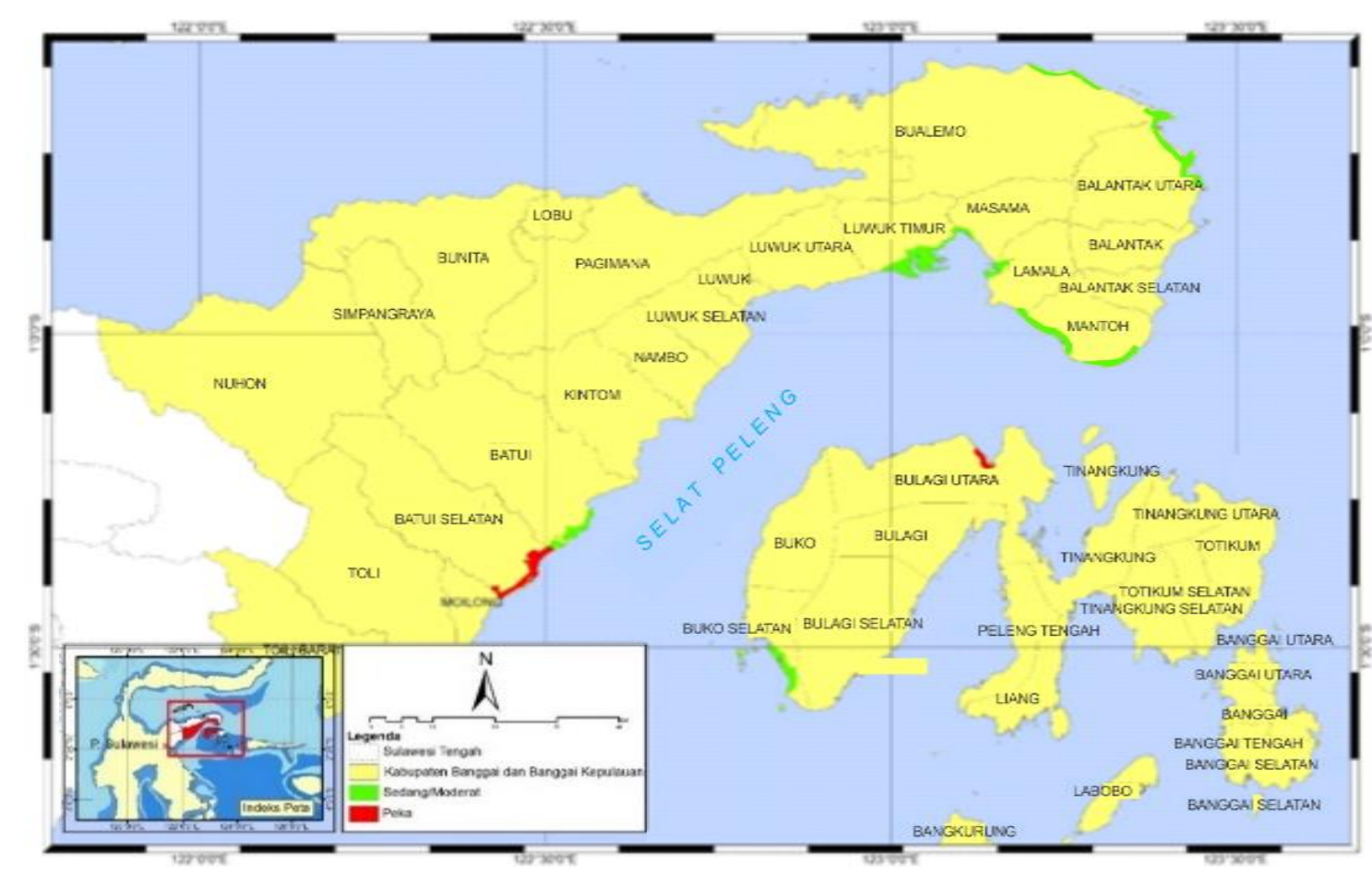

Figure 4. Mangrove distribution and ESI

\section{Total economic value (TEV)}

The TEV in this research is obtained by summing the DUV, IUV, and OV, and the result is US\$1,702,606/year or approximately US\$15,912/ha/year. The highest TEV is located in East Luwuk at US\$368,775.45/year, while the lowest is in Batui at US\$ 33,610.09/year (Table 5). Although East Luwuk has degradation of the mangrove ecosystem, it has a high utilization value. Moreover, East Luwuk has a long coastline covered by mangrove forests to protect from erosion.

Table 5. Result of calculation of value of exploiting of mangrove ecosystem at research location (in US\$)

\begin{tabular}{c|c|c|c|c|c|c}
\hline \multirow{2}{*}{ District } & \multicolumn{2}{|c|}{ DUV } & \multicolumn{2}{c|}{ IUV } & \multirow{2}{*}{ OV } & TEV \\
\cline { 2 - 5 } & $\begin{array}{c}\text { Par value of } \\
\text { wood }\end{array}$ & $\begin{array}{c}\text { Par value } \\
\text { of crab }\end{array}$ & $\begin{array}{c}\text { Biological } \\
\text { par value }\end{array}$ & $\begin{array}{c}\text { Physical par } \\
\text { value }\end{array}$ & & \\
\hline South Batui & $76,692.37$ & 855.19 & $1,550.83$ & $73,211.70$ & 150.00 & $152,460.09$ \\
Batui & $2,370.53$ & 799.25 & $1,125.64$ & $29,284.68$ & 0.03 & $33,610.09$ \\
East Luwuk & 0.00 & 770.18 & $1,721.76$ & $366,058.52$ & 225.00 & $368,775.45$ \\
Masama & $5,552.89$ & $1,257.14$ & 970.83 & $146,423.41$ & 150.00 & $154,354.27$ \\
Lamala & $70,203.68$ & $1,515.79$ & $1,506.54$ & $109,817.55$ & 225.00 & $183,268.57$ \\
Balantak & $101,512.89$ & 933.87 & $1,691.20$ & $109,817.55$ & 225.00 & $214,180.52$ \\
Bualemo & $88,312.63$ & $2,442.11$ & $1,970.90$ & $183,029.26$ & 375.00 & $276,129.90$ \\
Bulagi & $46,293.16$ & 649.62 & $1,979.02$ & $146,423.41$ & 150.00 & $195,495.21$ \\
Buko & $47,199.21$ & $1,418.80$ & $2,426.92$ & $73,211.70$ & 0.75 & $124,331.63$ \\
Total (US\$/thn) & $438,137.37$ & $10,641.94$ & $14,943.64$ & $1,237,277.78$ & $1,605.00$ & $1,702,605.73$ \\
\hline Percentage (\%) & 25.73 & 0.63 & 0.88 & 72.67 & 0.09 & 100.00 \\
\hline
\end{tabular}


The IUV takes the highest portion of TEV of $72.67 \%$ (IUV), while the lowest is the OV of $0.09 \%(\mathrm{OV})$, and the rest is from the direct OV of $25.73 \%$ (DUV). The highest IUV is derived from the mangrove value as a breakwater. Presented below is a comparison of TEV with other locations in Table 3. Generally, the higher contribution of TEV is come from IUV, due to the long coastline covered by mangrove forests to protect from erosion.

Based on tabulation in a hectare, the TEV of mangroves in this research is US\$ 15.912 per hectare or US\$ 1.59 per square meter. This research is much more extensive than Indrayanti and Fahrudin (2015), research in Blanakan Bay West Java, Indonesia, with 782.34 ha of plots for mangrove sampling and a 6,800-m coastline, with ecosystem services of US \$286,901.50/year or approximately US\$366.72/year/ha or US\$ $0.04 / \mathrm{m} 2$. However, Indrayanti, do not calculate the DUV such as wood utilization, fishing, and coastal line.

These are shown in Table 6 is an example of some of the economic valuation of mangrove in Indonesia.

Table 6. Economic value of mangrove ecosystem some regions in Indonesia (US \$)

\begin{tabular}{c|c|c|c|c|c|c|c|c}
\hline & \multicolumn{2}{|c|}{$\begin{array}{c}\text { Banggai dan Banggai } \\
\text { Islands }\end{array}$} & \multicolumn{2}{|c|}{ North Minahasa $^{1}$} & \multicolumn{2}{c|}{ Tanjung Pinang $^{\mathbf{2}}$} & \multicolumn{2}{c}{ Kendal $^{\mathbf{3}}$} \\
\cline { 2 - 9 } & $\mathbf{( U S \$ )}$ & $\mathbf{( \% )}$ & $\mathbf{( U S \$ )}$ & $\mathbf{( \% )}$ & $\mathbf{( U S \$ )}$ & $\mathbf{( \% )}$ & (US\$) & $(\boldsymbol{\%})$ \\
\hline DUV & 448,779 & 25.73 & 13,180 & 1.61 & $3,994,846$ & 60.20 & 46,796 & 42.94 \\
IUV & $1,252,221$ & 72.67 & 802,378 & 98.01 & $2,634,586$ & 39.70 & 61,518 & 56.45 \\
OP & 1,605 & 0.09 & 3,105 & 0.38 & 6,833 & 0.10 & 668 & 0.61 \\
TEV & $1,702,606$ & 100 & 818,663 & 100 & $6,636,265$ & 100 & 108,983 & 100 \\
\hline
\end{tabular}

${ }^{1}$ Suzana at al. (2011)

${ }^{2}$ Zen (2014)

${ }^{3}$ Fadhila and Saputra (2015)

\section{Oil spill spread}

This model is made with two scenarios of oil spill locations: the first scenario is in DSLNG Port (coordinate of $1^{\circ} 15.104^{\prime} \mathrm{S} ; 122^{\circ} 35.630^{\prime} \mathrm{E}$ ) and the second is in Luwuk Southern Port or the cape of Peleng Strait (coordinate of $1^{\circ} 28.260^{\prime} \mathrm{S} ; 1^{\prime} 2^{\circ} 36.350^{\prime} \mathrm{E}$ ). The first location is an LNG loading and unloading activities area, while the second location is in a tanker ship traffic route leading north. The results of model simulation provide data about the percentage of oil spills stranded on the shore. The results are displayed in the geographic information system (map) in each month in one year and for impact analysis in one year. The monthly data are grouped into four seasons: west season (Dec-Feb), transition season 1 (Mar-Apr), east season (May-Sep), and transition season 2 (Oct-Nov).

\section{Scenario 1 (DSLNG Port)}

Generally, oil spill spreading in west side is influenced mostly by the west season, and the oil spill moves toward the east, as shown in Figure 5 (Jan and Feb). Oil will be stranded on the coast along Batui, Kintom, and Nambo. Mangroves on the Batui Coast are in poor criteria (with $750 \mathrm{ind} / \mathrm{ha}$ ), while there is no mangrove habitat in Kintom and 
Nambo, which are sandy beach and settlement areas. Oil spills also spread to the north of Peleng Island, specifically in Bulagi, which has mangrove forests with good criteria $(1,450 \mathrm{ind} / \mathrm{ha})$.

In transition season 1, the wind tends to fluctuate not only from one direction but also from the north and northwest. Figure 5 (Mar and Apr) shows the oil spread to the southeast or toward Peleng Island. The oil spreads eastward along the coast of Banggai toward the north, but its spread is limited and does not reach Luwuk City. Oil will be stranded on the coast of Batui, Kintom, and Nambo, but only Batui has a mangrove area with poor criteria. Oil spreads toward Peleng Island, specifically in Buko, which has no mangrove area, just a rocky sand beach without a settlement area. Oil spreading in the east side is influenced mostly by the east season, and the oil spill moves toward the southwest, as shown in Figure 5 (May and Jun). The mangrove areas affected by the oil spill are located along Batui.
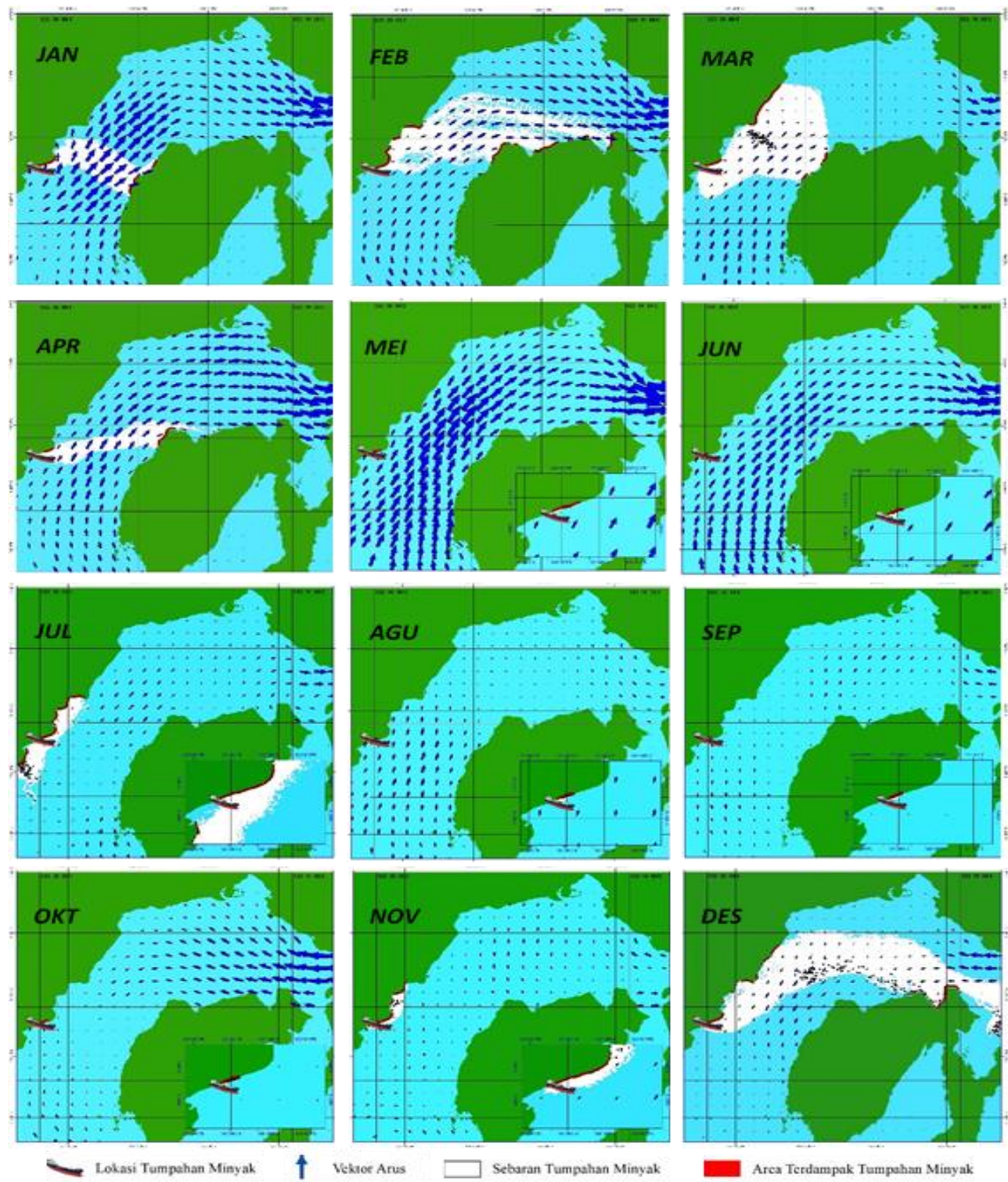

Figure 5. The spread of the oil spill scenario 1 on each month 
South Batui. In May and June, oil spills around Batui Beach extend to South Batui in July and finally begin to decrease in August and September. In transition season 2, the influence of the western season is beginning and increased with pressure from the west wind. The result of oil spreads to the east is shown in Figure 5 (Oct and Nov). The thin layer of oil begins to spread eastward along the coast of Banggai toward the north, but its spread is finite and does not reach Luwuk City, and it will be stranded along the coast of Batui and Kintom.

\section{Scenario 2 (narrow water of Pelang Strait)}

Oil spills in the west side in scenario 2 are influenced mostly by the west season, and the movement of the oil spill moves eastward and enters Maluku Sea, while the thin layer is stranded around the coast of the Banggai Islands. As shown in Figure 6 (Jan and Feb), the oil will spread toward the east in a narrow of Peleng Strait and be stranded in the north of the Banggai Islands, which do not have a mangrove area.

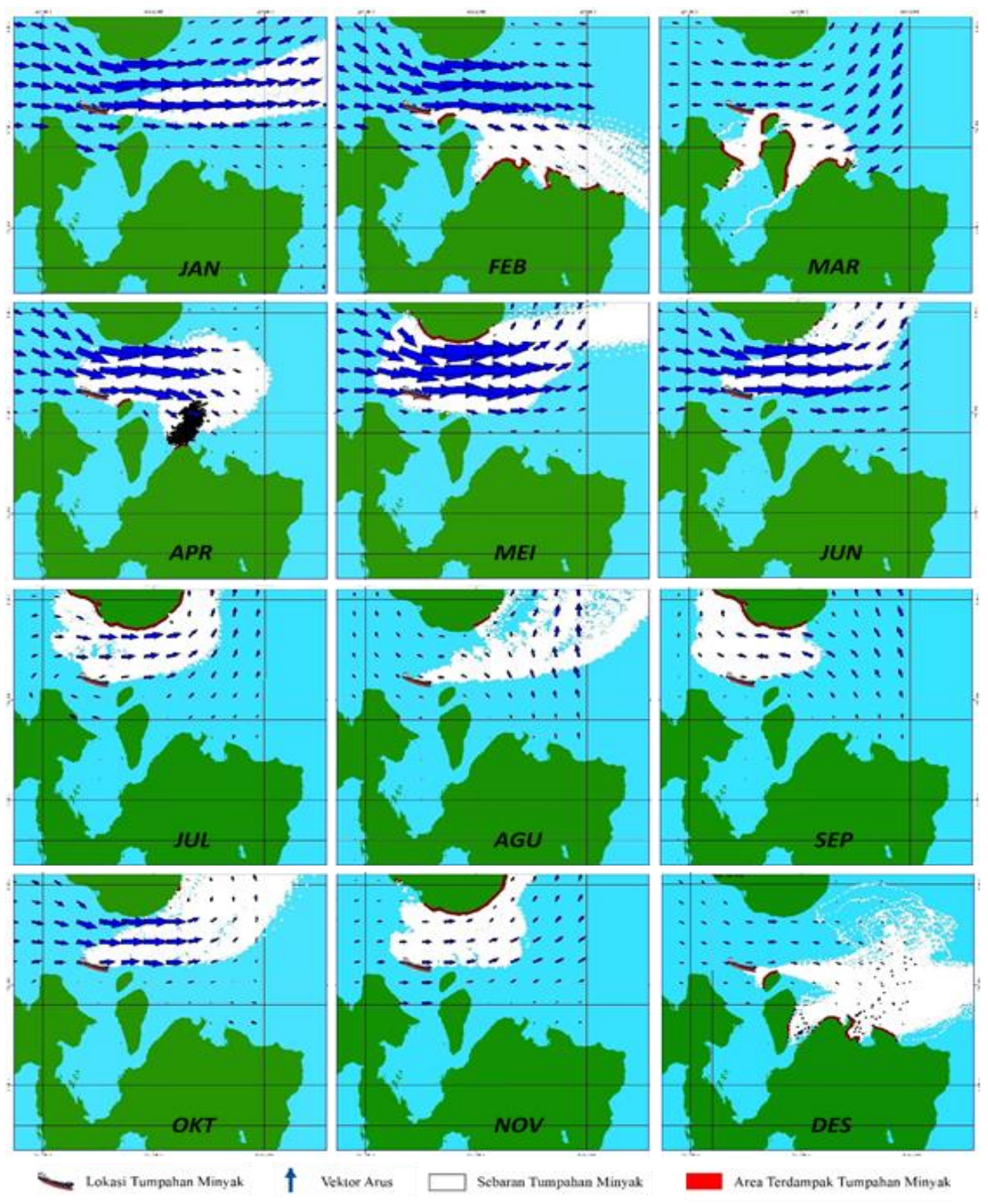

Figure 6. The spread of the oil spill scenario 2 on each month 
In transition season 1, the influence of the west season begins to decrease and has added pressure from the east wind, and then the oil will be stuck in the narrow of Peleng Strait, while some layers will be stranded in the cape of the Banggai Islands. The oil will turn to the cape of the Banggai Islands, and most will be stranded in the mangrove area. In April (Fig. 6 Apr), oil will be held in the narrow of Peleng Strait, and part of a thin layer will spread out into Maluku Sea.

In the east season (dry months) still influenced by strong western currents from Peleng Strait, and then the oil spill will move to the north. Oil tends to spread northward and is also influenced by pressure from eastern currents. In September (Fig. 6), the current enters Peleng Strait, and a thick layer of oil is spread over the mouth of Peleng Strait. In July and September (Fig. 6 Jul), a lot of oil is stranded on the coast of Bualemo Beach, which has mangrove areas.

In transition season 2, the influence of the west season begins with pressure from the west wind, and then the oil spreads back toward the east. A thin layer of oil moves eastward along the coast of Balantak to Bualemo and is then stranded along the Balantak North Coast. Many mangroves are found there, which will cause a large impact if a lot of oil is stranded in the mangrove area.

\section{Integration model}

The integration model is combine the Oil Spill Modelling (calculation the spill stranded), ESI, and TEV (calculation the loss value due to oil spill) and it can display spatially the distribution of oil spills, the value of mangrove sensitivity index and the value of environmental damage to mangrove ecosystems.

\section{Estimated volume of stranded oil}

The stochastic model is used to estimate the magnitude of MFO that will be stranded on the coast. This model also predicts the travel time of oil to reach the shoreline and the quantity of stranded oil on the shore. The oil spill area is calculated from the tidal range that enters into the mangrove ecosystem and then multiplied by the quantity of stranded oil.

This model simulation used MFO. The amount of spill is 700 tons or 4,375 barrels (1/4 of total tanker fuel), and the American Petroleum Institute index is 33.7 with a density of $0.87 \mathrm{~g} / \mathrm{cm}^{3}$. According to Hoff (2014), this oil is categorized in the second group, which has the following characteristics: (1) volatile, (2) leaves residue after evaporation, (3) spreads rapidly, (4) does not have stable form emulsion, and (5) more bioavailable than light oils. Hence, this oil will more likely affect animals in the water and sediment.

Scenario 1 was simulated at the DSLNG port location $\left(1^{\circ} 15.104 ' \mathrm{~S} ; 122^{\circ} 35.630^{\prime} \mathrm{E}\right)$ for each season. Around $22.30 \%$ of mangrove forests in South Batui will be affected by an oil spill if it occurs in the east season, and Batui will always be affected by oil spills in any season, with the greatest impact percentage of transition season 2 of $30.27 \%$. Bulagi will only be affected if the oil spill occurs in the west season with $40 \%$. The overall percentage of the coastal stranded oil spill in scenario 1 is shown in Figure 5 and Table 7.

In scenario 2, the oil spill occurs south of Luwuk Port or Peleng Strait ( $1^{\circ} 28.260^{\prime} \mathrm{S}$ and $\left.122^{\circ} 36.350^{\prime} \mathrm{E}\right)$. An oil spill will have the greatest impact if it happens in transition season 2. The worst location affected is in Balantak with $84.50 \%$. In the east season, 
only Bulagi is affected by $44.75 \%$. The oil spill is not affected in the west and transition season 1. Details are presented in Figure 6 and Table 8.

Table 7. Percentage of oil spills stranded on shore in Scenario 1

\begin{tabular}{c|c|c|c|c|c}
\hline \multirow{2}{*}{ No } & \multirow{2}{*}{ District } & \multicolumn{4}{|c}{ Season } \\
\cline { 3 - 6 } & & West & Transition 1 & East & Transition 2 \\
\hline 1. & South Batui & - & - & 22.30 & - \\
2. & Batui & 10.57 & 6.65 & 28.77 & 30.27 \\
3. & Bulagi & 40 & - & - & - \\
\hline
\end{tabular}

Table 8. Percentage of oil spills stranded on shore in Scenario 2

\begin{tabular}{c|c|c|c|c|c}
\hline \multirow{2}{*}{ No } & \multirow{2}{*}{ District } & \multicolumn{4}{|c}{ Season } \\
\cline { 3 - 6 } & & West & Transition 1 & East & Transition 2 \\
\hline 1. & Lamala & - & - & - & 15.49 \\
2. & Balantak & - & - & - & 84.50 \\
3. & Bualemo & - & - & - & 55.24 \\
4. & Bulagi & - & - & 44.75 & - \\
\hline
\end{tabular}

\section{The loss value due to oil spil}

Hoff and Michel (2014), mention that mangroves are particularly vulnerable to oil exposure, which can cause death within weeks or months. This level of sensitivity depends on the type of mangrove and the type of oil. Light oils are more toxic compared to heavy oils. Oil with slow decomposition will be more toxic than oil with fast decomposition. Polyaromatic hydrocarbon $(\mathrm{PAH})$ is a toxic compound that causes the death of mangroves. Death begins with yellowing leaves leading to defoliation and, ultimately, the death of the tree. Accumulation of hydrocarbons in the substrate causes disruption to mangrove function. The results of research in Panama show that the effects to mangrove growth are different in diverse concentrations of hydrocarbons (Duke, 1997). The total lost value due to the oil spill can be calculated as = TEV (in affected areas) $\mathrm{x}$ affected mangrove area (\%) $\mathrm{x}$ response to damage/death (within one year).

The simulation results in scenario 1 (Table 9) are as follows: the highest cost of an oil spill, if it occurs in the west season, is US\$ 79,775.27 in Bulagi, while the lowest is in transition season 1 at US\$2,346.30 in Batui, as shown in Figure 7. The simulation results in scenario 2 (Table 10) are as follows: the biggest loss value of oil spill if it occurs in transition season 2 is US\$ $379,654.03$ in Bualemo, while the lowest is in the east season at US\$ 44,902.54 in Lamala. In comparison between these two scenarios, the incident of oil spill in scenario 2 will cause a greater loss (transition season 2 in Bualemo) than scenario 1 (west season in Bulagi) due to more oil being stranded in the mangrove ecosystem in Bualemo, and the TEV is the highest, as shown in Figure 8.

Compared with the TEV, the highest loss value percentage is about $40.85 \%$ of TEV, as shown in Figure 9. Based on Figure 9, the loss values are only $40.85 \%$ of all TEV. This means the impact of the oil spill does not influence some districts based on simulation, the other side distribution of the oil spill reaches only $100 \mathrm{~m}$ from the 
coastline due to high tide movement. Where the mangrove life on more than $100 \mathrm{~m}$ from the coast.

Table 9. The value of oil spill loss in Scenario 1

\begin{tabular}{c|c|c|c|c}
\hline \multirow{2}{*}{ District } & \multicolumn{4}{|c}{ Loss value by season (US\$) } \\
\cline { 2 - 5 } & West Season & Transition 1 & East Season & Transition 2 \\
\hline South Batui & - & - & $35,868.07$ & - \\
Batui & $2,594.71$ & $2,346.30$ & $3,748.05$ & $3,843.11$ \\
Bulagi & $79,775.27$ & - & - & - \\
TOTAL & $82,369.98$ & $2,346.30$ & $39,616.13$ & $3,843.11$ \\
\hline
\end{tabular}
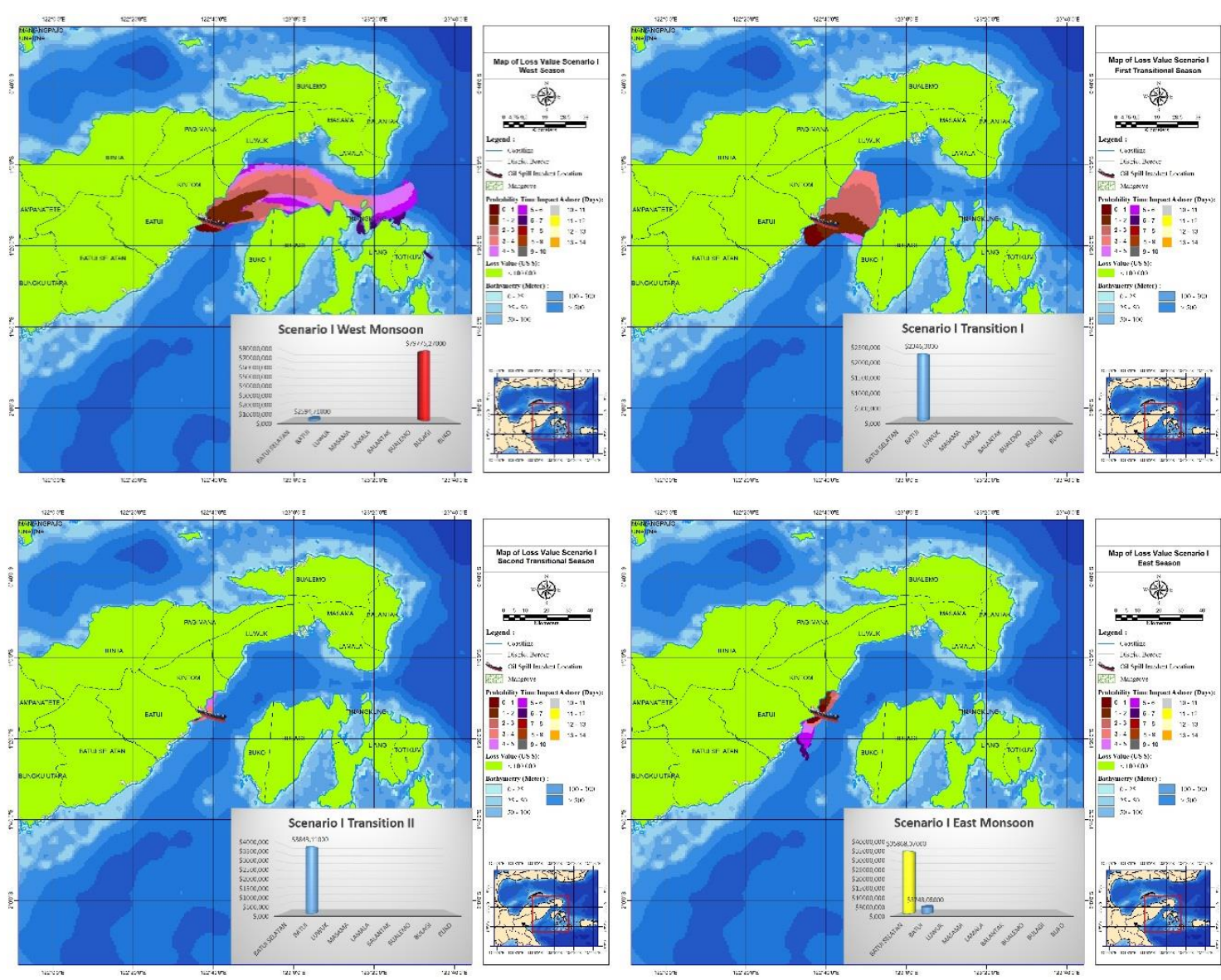

Figure 7. The lost value of the scenario 1 in the four seasons

Table 10. The loss due to oil spill in Scenario 2

\begin{tabular}{c|c|c|c|c}
\hline \multirow{2}{*}{ District } & \multicolumn{4}{|c}{ Loss value by season (US\$) } \\
\cline { 2 - 5 } & West & Transition 1 & East & Transition 2 \\
\hline Lamala & - & - & - & $44,902.54$ \\
Balantak & - & - & - & $270,965.40$ \\
Bualemo & - & - & - & $379,654.03$ \\
Bulagi & - & - & $88,936.43$ & - \\
TOTAL & - & - & $88,936.43$ & $695,521.97$ \\
\hline
\end{tabular}



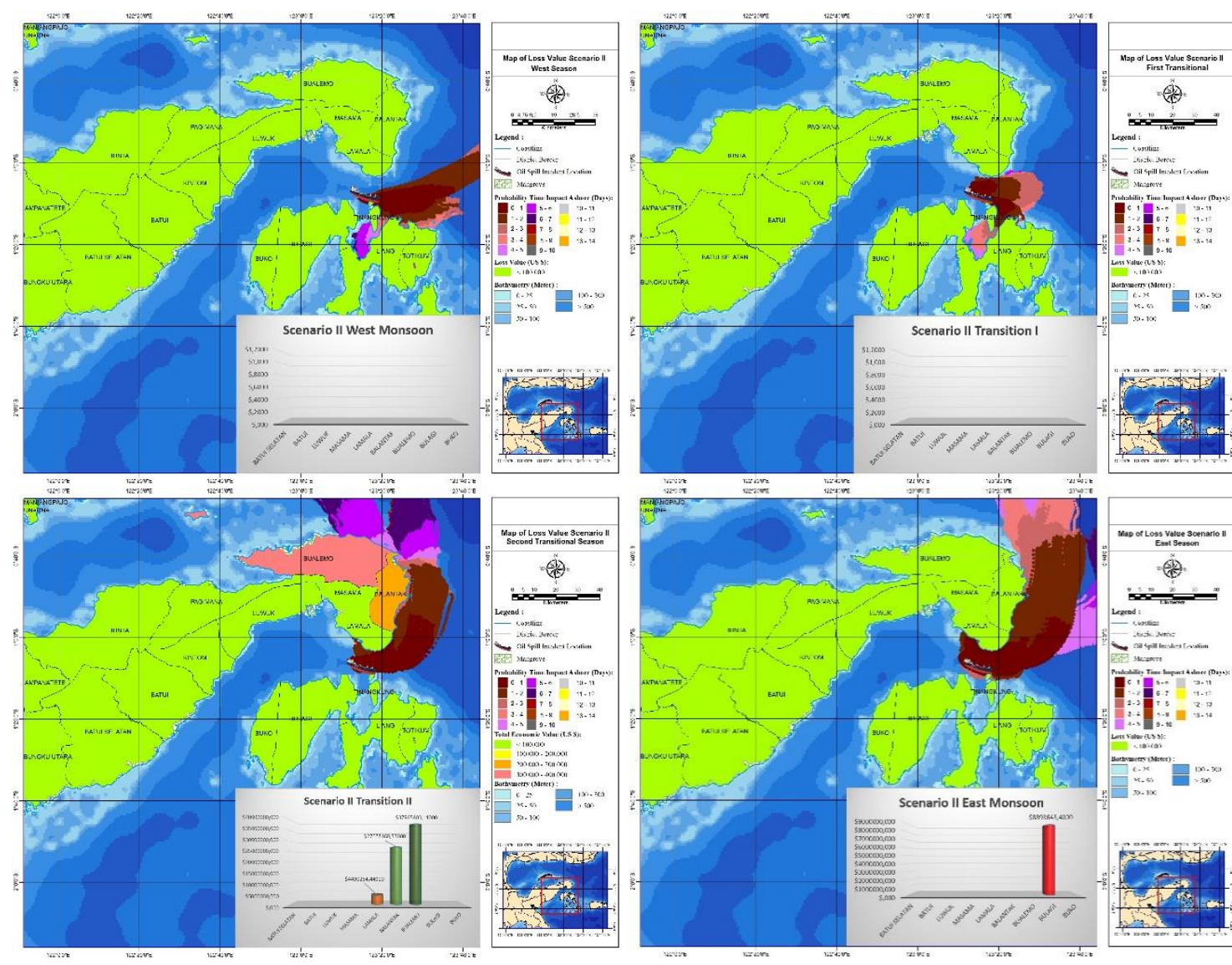

Figure 8. The lost value of the scenario 2 in the four seasons

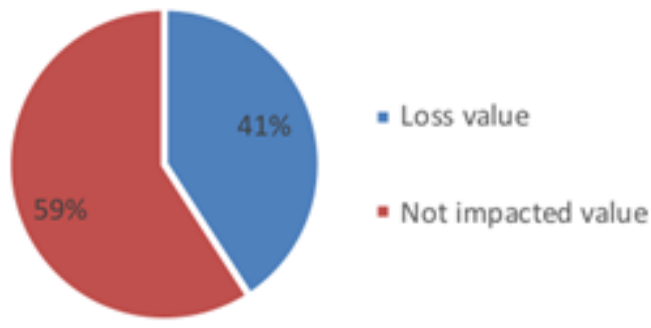

Figure 9. Compare highest loss value with not impact value

\section{Conclusion and future research}

Value of mangrove Sensitivity Index in the study locations ranged from moderate to sensitive. The TEV of mangrove ecosystem utilization is US $\$ 1,702,606 / y e a r$. The highest economic valuation is derived from the mangrove benefit as a breakwater, which comprises $72.67 \%$ of $\mathrm{TEV}$, followed by the value of mangrove benefit as building material at $25.73 \%$ and the lowest TEV as fishery products. Oil spill simulation results using two scenarios (at two locations) show that scenario 2 (mouth of Peleng Strait), which occurs during the transition season, will cause a greater loss of US\$ 695,328.20 than scenario 1 (DSLNG Port). The loss in scenario 1 is only US\$ 82,369.98, occurring in the west season, due to the spill reaching the big mangrove area. 2. The integration model can display spatially the distribution of oil spills, the 
value of mangrove sensitivity index and the value of environmental damage to mangrove ecosystems.

Continue this research by calculating the cleaning and recovery costs of an oil spill for the next few years until the ecosystem returns to its original state. Conduct research for the impact of oil spills on other ecosystems using economic assessments, such as the Coral Reef Ecosystem, Seagrass or Fishing Ground.

Acknowledgements. The author is very grateful to P. T. Donggi Senoro LNG (DSLNG) and Ph.D. promoters for support to complete this research. Not forgetting, especially for Prof. DR. H. S. Sanusi, MSc. for wholehearted support during my study.

\section{REFERENCES}

[1] Badan Pusat Statistik (BPS) (2016): Banggai Island Regency, Kabupaten Banggai Kepulauan dalam Angka. Salakan. - BPS, Jakarta.

[2] Badan Pusat Statistik (BPS) (2016): Banggai Regency, Kabupaten Banggai dalam angka. Luwuk. - BPS, Jakarta.

[3] Duke, N. C., Pinzon, Z. S., Prada, M. C. (1997): Large-scale Damage to Mangrove Forests Following Two Large Oil Spills in Panama. - Biotropica 29: 2-14.

[4] Fadhila, H., Saputra, S. W. (2015): Nilai Manfaat Ekonomi Ekosistem Mangrove di Desa Kartika Jaya Kecamatan Patebon Kabupaten Kendal Jawa Tengah. - Diponegoro J. Maquares 4(3): 180-187.

[5] Getter, C. et al. (1984): The Recovery and Restoration of Salt Marshes and Mangroves following an Oil Spill. - In: Cairns, J. J. Jr., Buikema, A. L. Jr. (eds.) Restoration of Habitats Impacted by Oil Spills. Butterworth Publishers, Boston.

[6] Giesen, W., Wulffraat, S. (2006): Mangrove Guidebook for Southeast Asia. - FAO and Wetlands International, Bangkok.

[7] Hoff, R., Michel, J. (2014): Oil Spills in Mangroves. - NOAA, Washington, DC.

[8] Indrayanti, M. D., Fahrudin, A. (2015): Penilaian Jasa Ekosistem Mangrove di Teluk Blanakan Kabupaten Subang. - J. Ilmu Pertan. Indones. 20(2): 91-96.

[9] Minister of Environment (2004): Number 201, Regarding Standard and Guideline of Mangrove Degradation. - Ministry of Environment, Jakarta.

[10] Sambu, A. H., Rahmi, R., Khaeriyah, A. (2014): Analysis of characteristics of and use value of mangrove ecosystem (case study in Samataring and Tongketongke Sub-Districts, Sinjai Regency). - J. Environ. Ecol. 5(2): 222-233.

[11] SI (2012): Studi Indeks Kepekaan Lingkungan PT. - Donggi Senoro LNG, Jakarta.

[12] Surveyor Indonesia (2012): Studi Indeks Kepekaan Lingkungan PT. - Donggi Senoro LNG, Jakarta.

[13] Suzana, F. A., Timbang, J., Kaunang, R. (2011): Valuasi Ekonomi Sumberdaya Hutan Mangrove di Desa Palaes Kecamatan Likupang Barat Kabupaten Minahasa Utara. - ASE 7(2): 29-38.

[14] Tempo (2018): The ecological impact of pertamina oil spill in Balikpapan Bay dampakTempo ekologis-tumpahan-minyak-pertamina-di-teluk-balikpapan. https://fokus.tempo.co/read/1077168/.

[15] Tomlinson, P. B. (1986): The Botany of Mangroves. - Cambridge University Press, New York.

[16] Zen, F. U. (2014): Valuasi Ekonomi Hutan Mangrove di Pulau Dompak Kota Tanjungpinang Provinsi Kepulauan Riau. - J. Din. Laut 4(1): 45-52. 